\title{
Compatibility of Entomopathogenic Nematodes with Neonicotinoids and Azadirachtin Insecticides for Controlling the Black Cutworm, Agrotis ipsilon (Hufnagel) in Canola Plants
}

\author{
${ }^{1}$ Mahmoud M.F.*, ${ }^{1}$ Mahfouz H.M., ${ }^{2}$ K.M. Mohamed \\ ${ }^{1}$ Plant Protection Department, Faculty of Agriculture, Suez Canal University, Ismailia, Egypt \\ ${ }^{2}$ Plant Production Department, Faculty of Environmental Agricultural Sciences, Suez Canal \\ University El-Arish, Egypt \\ mfaragm@hotmail.com
}

\begin{abstract}
Laboratory and greenhouse experiments were conducted to investigate the efficacy of the ntomopathogenic nematodes (EPNs), Steinernema carpocapsae, Heterorhabitis bacteriophora, two insecticides based on Azadirachtin and two Neonicotinoid insecticides. These treatments were applied alone or in combination against the last instar larvae of the black cutworm, Agrotis ipsilon (Hufnagel). The survival rates of S. carpocapsae and H. bacteriophora in the two group of insecticides have ranged between 96.1 to 99.7 after 72 hours of exposure. Data clearly indicated that S. carpocapsae was more virulent against A. ipsilon, whereas $H$. bacteriophora was less virulent at all concentrations under laboratory conditions. Mortality percentage increased significantly with increasing IJs concentration and time of exposure, reaching up to $100 \%$ and $90 \%$ at 160 infective juveniles (IJS) concentration, after 72 hours of exposure in $S$. carpocapsae and $H$. bacteriophora, respectively. Combination between EPNs at the rate of 80 IJs concentration and either each of the both group of insecticides (Azadirachtin and Neonicotioind) increaseing the efficacy of EPNs and mortality rates of A. ipsilon increased significantly under the laboratory condition. Results proved that S. carpocapsae and $H$. bacteriophora were less efficient under greenhouse condition when applied in combination with any of the insecticides at $5000 \mathrm{IJs} / 25 \mathrm{ml}$. EPNs efficacy in combination with Azadirachtin has mostly increased in comparison to EPNs with neonctinoid. This recommended that a mixture of Azadirachtin + EPNs could be applied for an efficient control of A. ipsilon.
\end{abstract}

Keywords: Entomopathogenic nematodes, Neonicotinoid, Azadirachtin, Compatibility, Agrotis ipsilon, canola plants

\section{INTRODUCTION}

The black cutworm, Agrotis ipsilon (Hufnagel) (Lepidoptera: Noctuidae) is a serious pest of several agricultural crops in Egypt and globally [1,2]. This noctuid insect is almost polyphagous attacks a large number of vegetable crops. The control of this pest has become a serious challenge facing applied entomologists nowadays considering the widening circle of resistance and cross resistance to conventional insecticides such as organophosphates and carbamates. This results in increased demands for pest control methods that are both efficient and environmentally friendly.

In Egypt, canola crop has a bright future to contribute in reducing oil deficiency gap between production and consumption [3, 4]. Growing canola still faces many challenges; one of them is being heavily infested with various insect pests, causing poor growth and low yield [5]. In Egypt, the most serious insect pests of canola in the seedling phase is the black cut worms, A. ipsilon.

Botanical insecticides can be used as a tool for a crop protection as one component of insect pest management [6]. Several researches confirmed that most of botanical insecticides are environmentfriendly because they have less toxicity to human and other non-target organisms [6, 7]. The neonicotinoid group of insecticides is among the most broadly adopted, conventional management tools for insect pests of annual and perennial cropping systems [8]. Benefits of the neonicotinoid group of compounds include flexibility of application, diversity of active ingredients, and broad spectrum activity [9].

The use of entomopathogenic nematodes (EPNs) (Rhabditida: Steinernematidae and Heterorhabditidae) has been successful used in many countries to control various crop pests, especially those that traverse the soil or inhabit cryptic environments [10]. EPNs of the Steinernema 
and Heterorhabditis genera live in the soil and are natural parasites of insects found in this ecosystem, as well as having a symbiotic relationship with bacteria of the Xenorhabdus and Photorhabdus genera, respectively [11]. EPNs are now applied against wide range of foliar pests [12, 13, 14]. The black cut worm, A. ipsilon were reported to be susceptible to EPNs $[15,16]$.

There are also no difficulties to apply EPNs via different techniques and they can be combined with almost all chemical control compounds [17, 18, 19]. The exposure of EPNs on foliage to extreme temperature, ultraviolet (UV), light and rapid fluctuation in moisture that causes desiccation reduces their potential as bio-control agents against foliage-feeding insect pests. Accordingly, EPNs applied to foliage must be protected from these detrimental environmental effects by avoiding high temperature and UV radiation with evening applications and desiccation by using adjuvants or anti desiccants. These additives are useful when nematodes are applied to waxy and glabrous leaves such as canola plants.

The objective of this study was to 1) determine the survival rates of EPNs Steinernema carpocapsae and Heterorhabditis bacteriophora with selected insecticides. 2) to investigate their efficacy against the black cutworms, A. ipsilon when applied alone or in combination with two group of insecticides, azadirachtin and neonictinoid in the laboratory and the greenhouse.

\section{Materials AND Methods}

\subsection{The Black Cutworm Rearing}

Eggs and newly larvae were collected from infested canola plants at the Experimental farm, Faculty of Agriculture, Suez Canal University, Ismailia. They were transferred to laboratory and supplied with castor bean leaves. (Ricinus communis) to feed the young larvae. To avoid cannibalism, the larvae were reared individually in a separate unit of plastic cell tray $(10.8 \times 22.7 \mathrm{~cm})$. The leaves were daily replaced with fresh ones. Newly formed pupae were collected and kept in glass jar containing moist saw dust and covered with muslin until adult emergence. Food was provided daily by using a cotton pad soaked in $10 \%$ honey solution, and then eggs were daily collected.

\subsection{The Greater Wax Moth Maintenance}

The greater wax moth larvae of Galleria mellonella $\mathrm{L}$. were used to produce progeny of nematode species. The insect culture was reared in $1500 \mathrm{ml}$ volume glass containers $(11 \mathrm{~cm}$ diameter and $15 \mathrm{~cm}$ height) at $25 \pm 2{ }^{\circ} \mathrm{C}$ on an artificial medium reported by [20]. The glass containers were closed with filter paper and a metal screen. Mature females insects laid their eggs on the filter paper which was transferred to fresh artificial medium in the rearing container. The eggs hatched within 3-4 days and larvae were fed weekly. After 5-6 weeks, larvae reached the last instar and were collected to be used for nematode propagation.

\subsection{Entomopathogenic Nematodes}

Entomopathogenic nematodes, Steinernema carpocapsae (Wieser) All strain and Heterorhabditis bacteriophora (Poinar) BRT strain were used in this experiments to investigate their efficacy to larvae of the black cut worms, A. ipsilon. EPNs were propagated in the last instar larvae of $G$.mellonella using the method of [20]. The infective juveniles (IJs) were collected in modified White traps [21], and stored in sterilized distilled water at $5{ }^{\circ} \mathrm{C}$ for no more than two weeks before they were used.

\subsection{Insecticides}

Two groups of insecticides based on Neonicotinoid and Azadirachtin were used in this study. The first group was Imidacloprid: (Best 25\% WP), applied at $0.18 \mathrm{~g}^{-1}$ water and the second one was Thiamethoxam: (Actara 25\% WG) applied at $0.5 \mathrm{~g}^{-1}$ water. While the other group was NeemAzal T/S $1 \%$ at the rate $0.1 \%$ and Neemix $4.5 \%$ at the same rate of $0.1 \%$. All insecticides were applied at low dose in compatible with EPNs.

\subsection{Survival Rates of EPNs Combined with Insecticides}

The concentration of $50 \mathrm{IJs} / 2 \mathrm{ml}$ distilled water was prepared in $5 \mathrm{~cm}$ diameter Petri-dish, filled individually with $2 \mathrm{ml}$ of each insecticides and distilled water (control) and kept for three days. The experiments were repeated twenty times and the dishes were kept at $25 \pm 2{ }^{\circ} \mathrm{C}$ in the laboratory. Number of alive IJs was counted after 24, 48 and 72 hours. 


\subsection{Laboratory Bioassay}

\subsubsection{EPNs Alone}

Experiments with last instar larvae of A. ipsilon were conducted in Petri-dishes (90 mm diameter) lined with filter paper (Whatman No.1). Each dish was inoculated with one of the two nematode species at seven concentrations $(0,20,40,80$ and $160 \mathrm{IJs} / \mathrm{ml})$. The number of IJs were counted under a dissecting zoom microscope to check nematode viability. All plates were sealed and incubated at 25 $\pm 2{ }^{\circ} \mathrm{C}$. There were twenty plates; one larva in a dish is an experimental unit. After 72 hours of contact period, dead larvae were individually transferred to modified white traps [21] to evaluate nematode infectivity, mortality and emergence of nematode progeny.

\subsubsection{EPNs in Combination with Insecticides}

The concentration of $80 \mathrm{IJs} / \mathrm{ml}$ distilled water was prepared in Petri-dishes (90 mm diameter) lined with filter paper (Whatman No.1), filled individually with $1 \mathrm{ml}$ of each insecticides at the selected concentration, and kept for 72 hours. Distillated water was used as controls. The experiments were repeated 20 times and the dishes were kept at $\left(25 \pm 2^{\circ} \mathrm{C}\right)$. Dead larvae were individually transferred to modified white traps [21] to evaluate nematode infectivity, mortality and emergence of nematode progeny.

\subsubsection{Greenhouse Bioassay}

Greenhouse study was conducted by spraying $25 \mathrm{ml}$ nematodes suspension on canola plants with $5000 \mathrm{IJs} / 25 \mathrm{ml}$ before flowering stage at evening hours $5.30 \mathrm{pm}$ to prevent desiccation induced by sunlight. Five plants 45 days after sowing were selected and twenty five, healthy and active last instar larvae of A. ipsilon were released individually on the leaves of canola plants and then spraying 5000 IJs/ $25 \mathrm{ml}$ of the two species of nematodes or $25 \mathrm{ml}$ distilled water (control). The percent larval mortality was recorded after 72 hours of nematodes application. Scoring of larvae mortalities was achieved by recovering dead larvae to confirm mortality due to EPNs. Later, larva stages of A. ipsilon are photo-negative and tend to hide in the soil during the daytime hours. Also, larvae tend to be cannibalistic so mortality of larvae could be due to intrinsic behavior of the species

\subsubsection{Statistical Analysis}

Data obtained in the present study was subjected to an analysis of variance (ANOVA) with the honestly significant difference value calculated as Tukey's statistic at $\mathrm{P} \leq 0.05$ [22].

\section{RESULTS AND DiscusSION}

The survival rates of $S$. carpocapsae and $H$. bacteriophora in the two group of insecticides have ranged between $99.0 \%$ to $99.7 \%$ in S. carpocapsae and $98.4 \%$ and $99.6 \%$ in H. bacteriophora after 24 hours, and $99.0 \%$ to $99.3 \%$ in S. carpocapsae and $98.2 \%$ to $99.3 \%$ in H. bacteriophora after 48 hours and $97.4 \%$ to $99.1 \%$ in S. carpocapsae and $96.1 \%$ to $99.1 \%$ in H. bacteriophora after 72 hours after application.

In appearance, the percentage of survival rates of nematodes has been compared between insecticides within species, by time point (column wise). Treatments of neemazal, neemix, imidacloprid and thiamethoxam did not show a significant difference of nematode survival rate with control $(100 \%)$ at 24, 48 and 72 hours. However, all nematode survival rates in the three times points of exposure were higher than $96.1 \%$ (Table 1). The result in Table 1 suggests no significant difference between control and insecticide groups in later time points. Nematode survival rates in this study were similar to that reported by [23] who indicated that a recommended rates of pesticides directly applied with $S$. carpocapsae had no effect on $S$. carpocapsae virulence (more than $96 \%$ survival rate) at room temperature for 3 hours. [24] confirmed that the compatibility between nematodes and botanical insecticides or chemical insecticides at recommended doses had no effects on survival rates after 72 hours of exposure.

Efficacy of five concentrations of EPNs S. carpocapsae and H. bacteriophora against last instar larvae of A. ipsilon was estimated after 42, 48 and 72 hours of exposure (Figs 1 and 2). Significant differences were found in virulence of both species of EPNs against larvae of A. ipsilon in filter paper assay under laboratory conditions. Mortality rates increased significantly with increasing nematode concentrations in the tested species. Also, in both nematode treatments the mortality was significantly 
higher than the mortality in control. Data clearly indicated that $S$. carpocapsae was virulent against the last instar larvae of $A$. ipsilon; wheareas $H$. bacteriophora was less virulent at all concentrations and time of exposure.

Table1. The survival rates of Steinernema carpocapsae and Heterorhabitids bacteriophora which were soaked in insecticides for 24, 48 and 72 hours.

\begin{tabular}{|c|c|c|c|c|c|c|}
\hline \multirow{2}{*}{ Treatments } & \multicolumn{9}{|c|}{ Survival rate after, } \\
\cline { 2 - 7 } & \multicolumn{2}{|c|}{$24 \mathrm{~h}$} & \multicolumn{2}{c|}{$48 \mathrm{~h}$} & \multicolumn{2}{c|}{$72 \mathrm{~h}$} \\
\cline { 2 - 7 } & $\begin{array}{c}S . \\
\text { carpocapsae }\end{array}$ & $\begin{array}{c}H . \\
\text { bacteriophora }\end{array}$ & $\begin{array}{c}\text { S. } \\
\text { carpocapsae }\end{array}$ & $\begin{array}{c}H . \\
\text { bacteriophora }\end{array}$ & $\begin{array}{c}\text { S. } \\
\text { carpocapsae }\end{array}$ & $\begin{array}{c}H . \\
\text { bacteriophora }\end{array}$ \\
\hline Control & $100 \mathrm{a}$ & $100 \mathrm{a}$ & $100 \mathrm{a}$ & $100 \mathrm{a}$ & $100 \mathrm{a}$ & $100 \mathrm{a}$ \\
\hline Imidacloprid & $99.0 \mathrm{a}$ & $98.4 \mathrm{a}$ & $99.0 \mathrm{a}$ & $98.2 \mathrm{a}$ & $98.3 \mathrm{a}$ & $98.1 \mathrm{a}$ \\
\hline Thiamethoxam & $99.1 \mathrm{a}$ & $99.0 \mathrm{a}$ & $99.0 \mathrm{a}$ & $98.8 \mathrm{a}$ & $97.4 \mathrm{a}$ & $96.1 \mathrm{a}$ \\
\hline Neemazal & $99.7 \mathrm{a}$ & $99.5 \mathrm{a}$ & $99.5 \mathrm{a}$ & $99.3 \mathrm{a}$ & $99.1 \mathrm{a}$ & $99.1 \mathrm{a}$ \\
\hline Neemix & $99.7 \mathrm{a}$ & $99.6 \mathrm{a}$ & $99.3 \mathrm{a}$ & $99.2 \mathrm{a}$ & $99.0 \mathrm{a}$ & $99.1 \mathrm{a}$ \\
\hline
\end{tabular}

Percentages followed with the same letters (column wise) are not significantly different (Tukey' HSD; $P \leq 0.05$ )

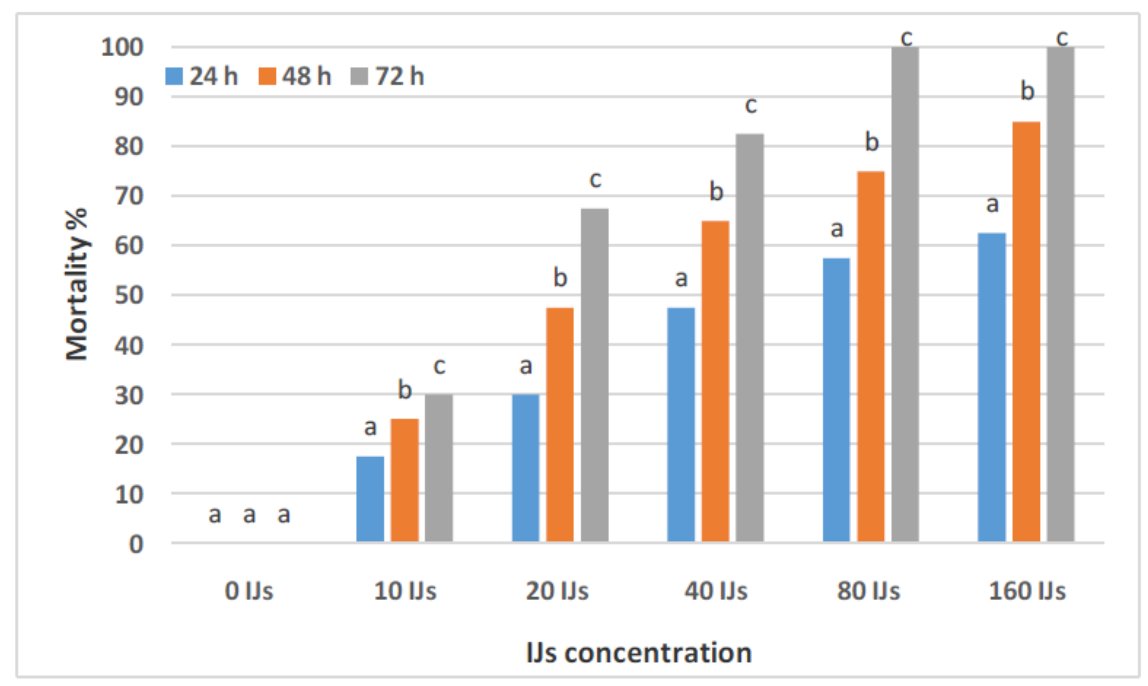

Figure1. Efficacy of EPN Steinernema carpocapsae against the last instar larvae of A. ipsilon in the laboratory

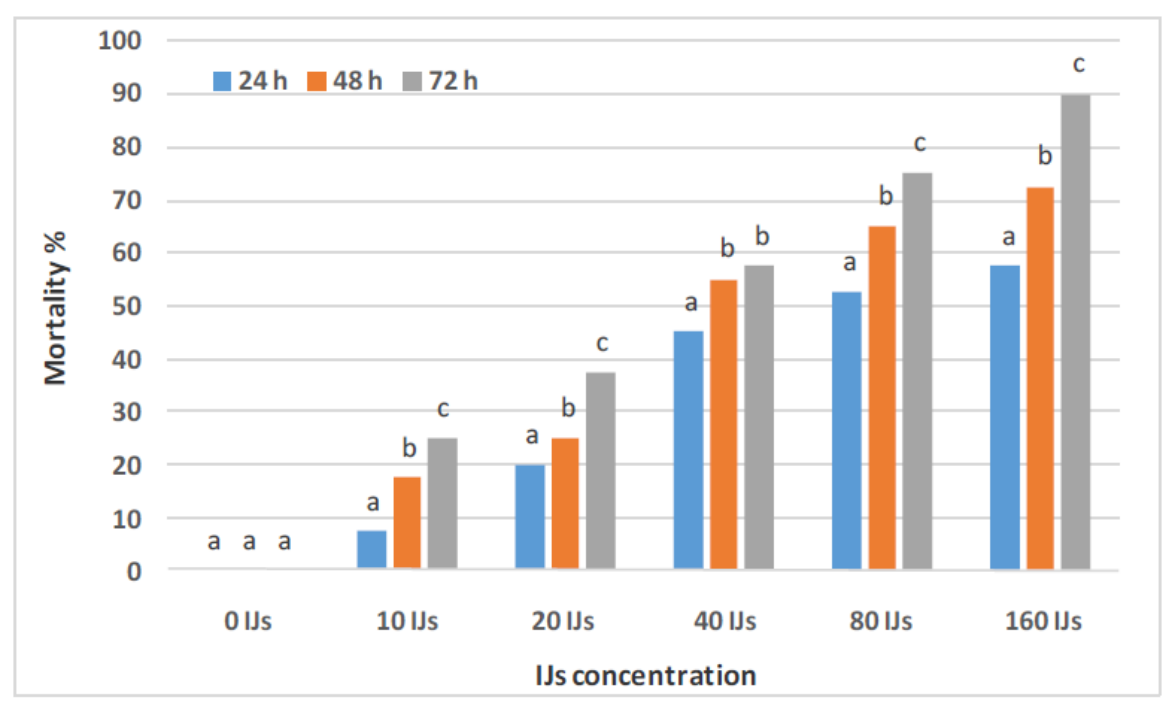

Figure2. Efficacy of EPN Heterorhabitis bacteriophora against the last instar larvae of A. ipsilon in the laboratory

The highest larval mortality was observed in S. carpocapsae + neemix treatment $(97.5 \%)$, followed by S. carpocapsae + neemazal treatment $(95 \%)$. Nevertheless, neonictinoid had lower larval mortalities $(85 \%)$ in S. carpocapsae + imidacloprid and S. carpocapsae + thiamethoxam (Figure 3 and 4). Efficacy of $H$. bacteriophora in combination with both insecticides was lower than that of $S$. carpocapsae when mixed with the same insecticides. It was ranged between (67.5 to $80 \%$ mortality). 
Results shows that both neonicotinoid insecticides in conjunction with EPNs did not produce higher mortality compared to $S$. carpocapsae alone.

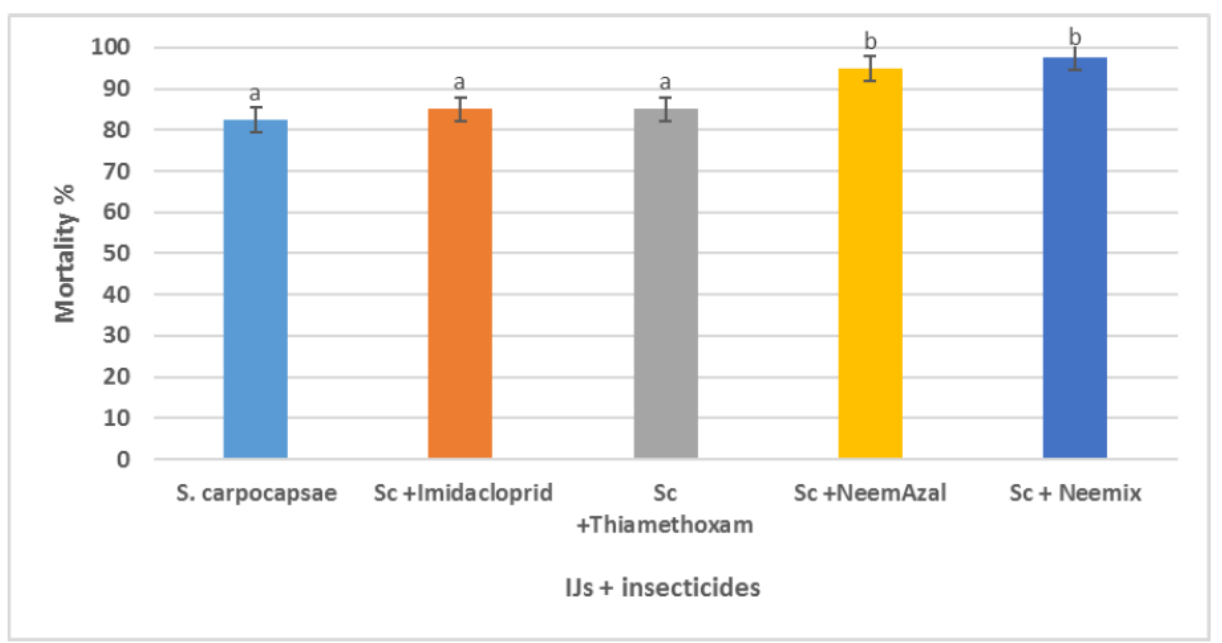

Figure3. Efficacy of EPN Steinernema carpocapsae at $80 \mathrm{IJ} /$ larva in combination with insecticides against the last instar larvae of $A$. ipsilon in the laboratory

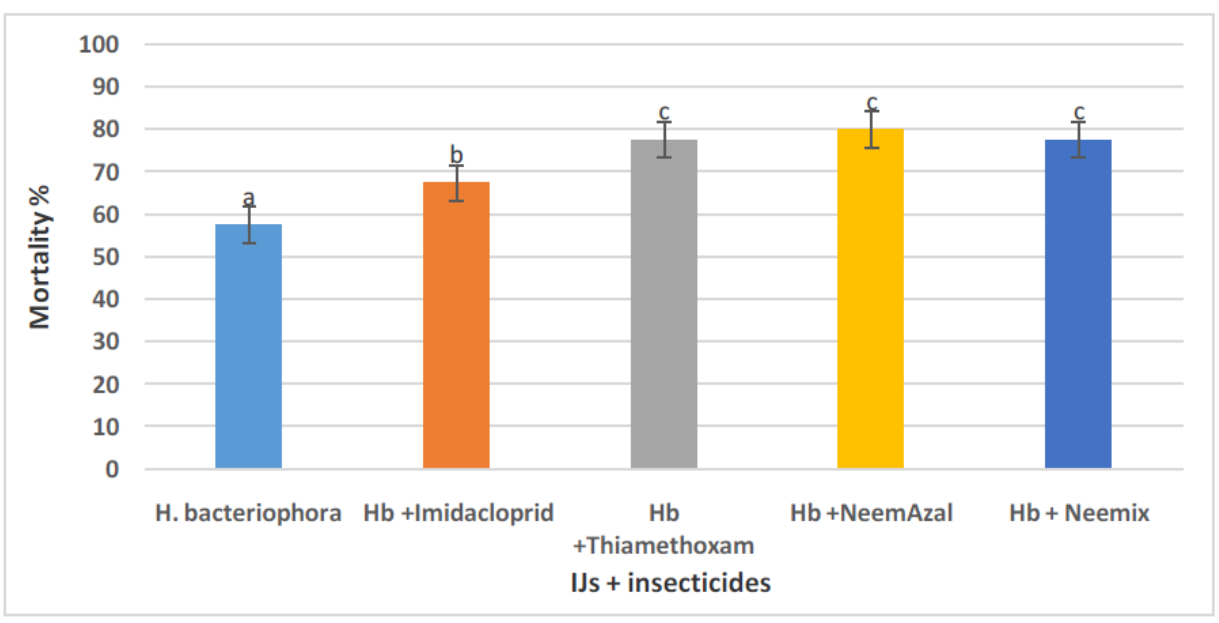

Figure4. Efficacy of EPN Heterorhabitis bacteriophora at $80 \mathrm{IJ}$ / / larva in combination with insecticides against the last instar larvae of A. ipsilon in the laboratory

In the greenhouse tests, $S$. carpocapsae in combination with imidacloprid, thiamethoxam, neemazal and neemix caused 47.5, 42.5, 62.5 and 50\% mortality, respectively against $A$. ipsilon compared to 30 $\%$ in control (S. carpocapsae alone). While, H. bacteriophora caused 30, 27.5, 45 and 50\% mortality compared to $25 \%$ in control. Greenhouse experiment has confirmed the results of filter paper assay. Data revealed that $S$. carpocapse was more virulence than $H$. bacteriophora when applied alone or in combination with insecticides (Figure 5 and 6). EPNs were capable of causing mortality in A. ipsilon in the tested conditions, demonstrating a potential for later tests under field conditions. [25] proved that EPN Heterorhabditis indica is a potential option for possible management, capable of nematode production with efficacy notable against cotton bollworm, Helicoverpa armigera and tobacco caterpillar, Spodoptera litura in soil and foliar spray in greenhouse.

Our results suggest that integration of EPNs in IPM programs in combination with other biocontrol agents and pesticides is possible since they are compatible. [26] reported that the survival rates of nematode after combining with $0.01 \%$ confidor (imidacloprid), $0.025 \%$ actara (thiomethoxan), $0.05 \%$ agropest BT, $0.05 \%$ conserve (spinosad) and 2.00\% neemglod (neem) were 97.2\%, 83.2\%, 93.6\%, $87.2 \%$ and $92.4 \%$, respectively.

S. carpocapsae combined with cypermethrin $(0.025 \mathrm{~L} / \mathrm{ha})$, chlorpyrifos $(0.300 \mathrm{~L} / \mathrm{ha})$ and lufenuron $(0.150 \mathrm{~L} / \mathrm{ha})$ had high efficiency against Spodoptera frugiperda (Smith) for 82.0, 90.0\% and 90.0\%, respectively [27]. Furthermore, [28] indicated an interaction between $S$. carpocapsae with proclaim $(0.125 \mathrm{mg} / \mathrm{L})$ with additive effect, producing mortality rates of forth instar larvae of Agrotis ipsilon up 
to $100 \%$. Whereas, nematode alone $(50 \mathrm{IJs})$ and proclaim $(0.125 \mathrm{mg} / \mathrm{L})$ had killed A. ipsilon larvae at $85 \%$ and $89 \%$, respectively. Nevertheless, this result also agreed with various researchers who reported that entomopathogenic nematode and pesticide have been compatible [29].

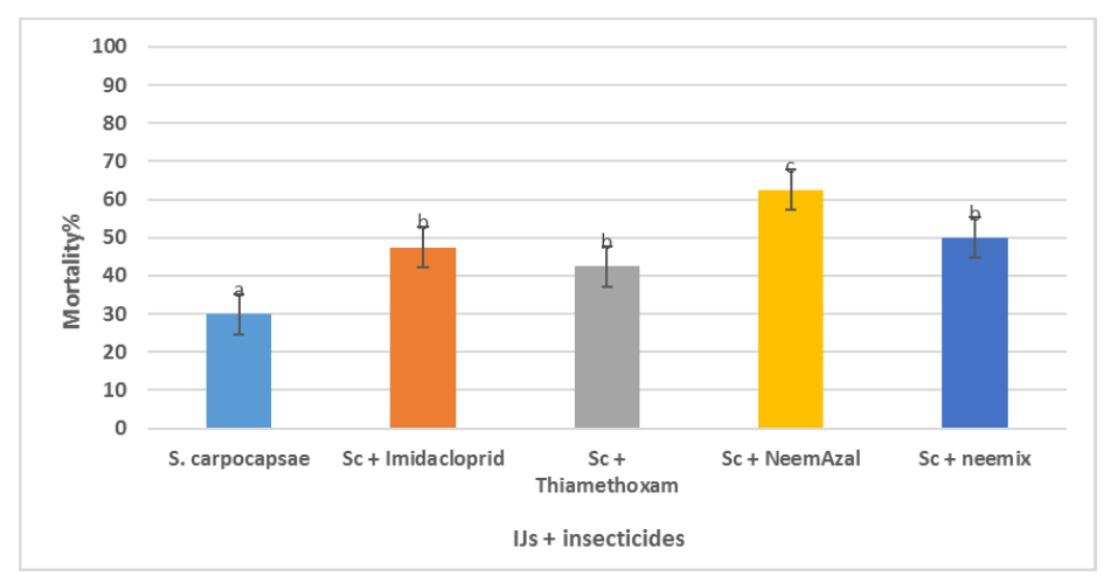

Figure5. Efficacy of EPN Steinernema carpocapsae at $5000 \mathrm{IJ} / 25 \mathrm{ml}$ in combination with insecticides against the last instar larvae of $A$. ipsilon in the greenhouse

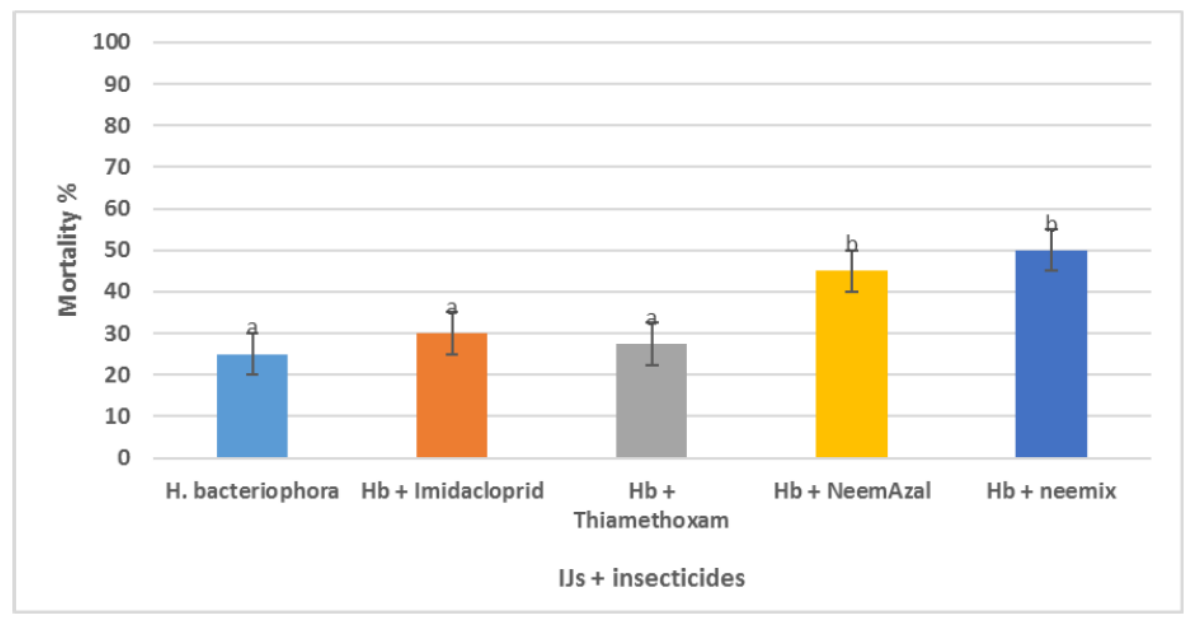

Figure6. Efficacy of EPN Heterorhabitis bacteriophora at $5000 \mathrm{IJS} / 25 \mathrm{ml}$ in combination with insecticides against the last instar larvae of A. ipsilon in the greenhouse

\section{CONClusion}

The study provides evidence that $S$. carpocapsae and $H$. bacteriophora under controlled laboratory conditions are able to exert an excellent degree of control over last instar larvae of $A$. ipsilon. Within the glasshouse situation a lower level of A. ipsilon mortality was obtained. However, the compatibility of $S$. carpocapsae, H. bacteriophora and neonctinoid, azadirachtin insecticides gives potential for the incorporation of EPNs into integrated pest management programmes for the control of A. ipsilon within canola greenhouse.

\section{REFERENCES}

[1] JL Capinera, 2001. Handbook of vegetable pests. Academic Press, San Diego, 2001, 729 pp.

[2] Sharaby A. and El-Nojiban A., Evaluation of some plant essential oils against the black cutworms Agrotis ipsilon. Global Journal of Advanced Research. 2(4), 701-711 (2015).

[3] El-Howeity M.A. and Asfour M.M., Response of some varieties of canola plant (Brassica napus L.) cultivated in a newly reclaimed desert to plant growth promoting rhizobacteria and mineral nitrogen fertilizer. Annals of Agricultural Sciences 57(2),129-136 (2012).

[4] Sharaan A.N., Ghallab K.H. and Yousif K.M., Performance and water relations of some rapeseed genotypes grown in sandy loam soils under irrigation regimes. Annals of Agric. Sc., Moshtohor 40(2), 751-767 (2002).

[5] Dosdall L.M. and Mason P.G., 2010. Key pests and parasitoids of oilseed rape or canola in North America and the importance of parasitoids in integrated management. Springer, 167- 213 (2010). 
[6] Dadang E.D., Fitriasari and Prijono D., Effectiveness of two botanical insecticide formulations to two major cabbage insect pests on field application. Journal of the International Society for Southeast Asian Agricultural Sciences 15, 42-51 (2009).

[7] Isman M.B., Perspective botanical insecticides: for richer, for poorer. Pest Management Science 64, 8-11 (2008).

[8] Jeschke P., Nauen R., Schindler M. and Elbert A., Overview of the status and global strategy for neonicotinoids. J Agric. Food Chem. 59, 2897-2908 (2010).

[9] Elbert A., Haas M., Springer B., Thielert W. and Nauen R., Applied aspects of neonicotinoid uses in crop protection. Pest Manag Sci 64, 1099-1105 (2008).

[10] Mahmoud M.F., Virulence of Entomopathogenic Nematodes against the Jasmine Moth, Palpita unionals Hb. (Lepidoptera: Pyralidae). Egyptian J. of Biological Pest Control 24 (2), 393-397 (2014a).

[11] Forst S. and Clarke D., Bacteria-nematode symbiosis, CABI Publishing, Oxon, UK, 55-77 (2002).

[12] Brusselman E., Beck B., Pollet S., Temmerman F., Spanoghe P., Moens M. and Nuyttens D., Effect of the spray application technique on the deposition of entomopathogenic nematodes in vegetables. Pest Management Science 68, 444-453 (2012).

[13] Beck B.E., Brusselman D., Nuyttens M., Moens S., Pollet F. and Spanoghe P., Improving foliar applications of entomopathogenic nematodes by selecting adjuvants and spray nozzles. Biocontrol Science and Technology 23(5), 507-520 (2013).

[14] Mahmoud M.F., Efficacy of Entomopathogenic Nematodes to Certain Insect Pests infesting Oilseed Rape in the Laboratory and Greenhouse. Egyptian J. of Biological Pest Control 24 (2), 387-391 (2014b).

[15] Hussein Mona A., Utilization of entomopathogenic nematodes for biological control of some Lepidopterous pests. Ph. D. Thesis Fac. Sci. Ain Shams Univ., Pp 203 (2004).

[16] Ebssa L. and Koppenhöfer A.M., Entomopathogenic nematodes for the management of Agrotis ipsilon: effect of instar, nematode species and nematode production method. Pest Manag Sci. 68 (6), 947-57 (2012).

[17] Mahmoud M.F., Pomazkov Y.I., 2004. Efficiency of steinernematid nematodes in controlling larvae and pupae Delia antiqua in laboratory with reference to the effect of some insect growth regulators and entomopathogenic nematode Steinernema feltiae. Egyptian J. of Biological Pest Control 14 (2), 391-396 (2004).

[18] Mahmoud M.F., Combining the botanical insecticides NSK extract, NeemAzal T 5\%, Neemix 4.5\% and the entomopathogenic nematode Steinernema feltiae Cross N 33 to control the peach fruit fly Bactrocera zonata (Saundres). Plant Protection Sci. 43 (1), 19-25 (2007).

[19] Lanzoni A. Ade G., Martelli R., Radeghoeri P., Pezzi F., Technological aspects of Steinernema carpocapsae spray application alone or mixed with Bacillus thuringiensis aizawai in spinach crop. Bulletin of Insectology 67 (1), 115-123 (2014).

[20] Ehlers R., Mass production of entomopathogenic nematodes for plant protection. Appl. Microb. Technol. 56, 623-633 (2001).

[21] Kaya H.K. and Stock S.P., 1997. "Techniques in insect nematology," in manual of techniques in insect pathology, Academic Press, 281-324 (1997).

[22] SAS Institute Inc., Version 9.1 SAS/STAT Users Guide. Vol. 1 and 2.Cary, N C., USA (2004).

[23] Alumai A. and Grewal P.S., Tank-mix compatibility of the entomopathogenic nematodes, Heterorhabditis bacteriophora and Steinernema carpocapsae, with selected chemical pesticides used in turfgrass. Biocontrol Science and Technology 14, 725-730 (2004).

[24] Mahmoud M.F., Mosleh Y.Y. and Osman M.A.M., Effect of some botanical insecticides and insect growth regulators on viability, infectivity, motility and persistence of Entomopathogenic nematode Steinernema feltiae Cross N33. Agricultural Research Journal; Suez Canal University 6 (2), 95-99 (2006).

[25] Divya, K., and Sankar M., Entomopathogenic nematodes in pest management. Indian Journal of Science and Technology 2,53-60 (2009). 
[26] Kulkarni N, Paunikar S, Mishra VK, Daksh S, Tolerance of Entomophagenic nematode, Steinernema carpocapsae to some modern insecticides and biopesticides. Annals of Entomology 31, 129-134 (2013).

[27] Negrisoli A.S., Garcia M.S. and Negrisoli C.R.C.B., Compatibility of entomopathogenic nematodes (Nematoda: Rhabditida) with registered insecticides for Spodoptera frugiperda (Smith, 1797) (Lepidoptera: Noctuidae) under laboratory conditions. Crop Protection 29, 545549 (2010).

[28] Fetoh A.S., Khaled A.S. and EI-Nagar T.F.K., Combined effect of entomophagenic nematodes and biopesticides to control the greasy cut worm, Agrotis ipsilon (Hufn.) in the strawberry fields. Egyptian Academic Journal of Biological Sciences 2, 227-236 (2009).

[29] Koppenhöfer A.M. and Grewal P.S., Compatibility and interactions with agrochemicals and other biocontrol agents. CABI Publishing, Wallingford, UK. (2005).

\section{AUTHORS' BIOGRAPHY}

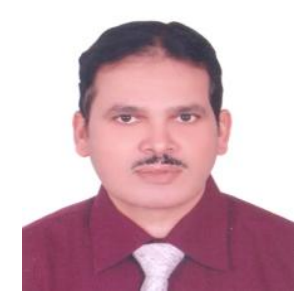

Dr. Mahmoud Farag Mahmoud, Professor of Economic Entomology, Faculty of Agriculture, Suez Canal University.

mfaragm@hotmail.com,mfaragm@agr.suez.edu.eg

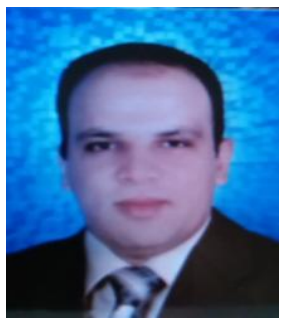

Dr. Hatem Mohamed Mahfouz, Lecturer of Economic Entomology, Faculty of Environmental Agricultural Sciences, Suez Canal University.

hatemmahfouz@yahoo.com

Dr. Kariman Mahmoud Mohamed, Lecturer of Economic Entomology, Faculty of Agriculture, Suez Canal University. 